Zavoda za znanstveni rad Izvorni znanstveni članak HAZU Varaždin

\title{
HRVATSKO-SLOVENSKI ODNOSI NA PODRUČJU GRANIČNE ZONE VARAŽDINSKE ŽUPANIJE'
}

Autor u tekstu donosi informacije o hrvatsko-slovenskim odnosima na području Varaždinske županije. Prostor granice u znanstvenom smislu do danas je vrlo rijetko promatran kroz iskaze pojedinaca koji žive u pograničnom prostoru, pa je stoga ovo istraživanje drugačije, budući da se temelji na doživljaju i iskustvima ljudi koji stanuju uz hrvatskoslovensku granicu. Istraživanje je pokazalo da su stanovnici s jedne i s druge strane granice mnogo više orijentirani jedni na druge nego što su povezani sa svojim regionalnim središtima. Granica je uvelike poremetila odnose Hrvata i Slovenaca s obje strane, a ti odnosi do danas, usprkos ulasku Hrvatske i Slovenije u Europsku uniju, nisu vraćeni u nekadašnje okvire. Ovim se radom želi pokazati na koje su sve načine postojale veze između jednog i drugog prostora te koliko su te veze narušene nakon uspostave granice 1991. godine. $U$ istraživanju je primijenjen povijesni i etnološki pristup koji je vidljiv iz prikupljanja podataka iz matičnih knjiga umrlih i vjenčanih, odnosno iz metode usmene povijesti i prikupljanja priča kazivača. Na temelju matičnih knjiga umrlih i vjenčanih župa Nadkrižovljan, Križovljan, Višnjica, Voća, Cvetlin i Bednja autor donosi podatke o intenzitetu kontakata Hrvata i Slovenaca u pograničnoj zoni Varaždinske županije. Vidljivo je da su te veze bile uske tijekom gotovo petstoljetne povijesti u zajedničkoj državi. Iz provedenih intervjua na području Grada Lepoglave te Općine Donja Voća i Općine Bednja vidljivo je da su stanovnici pograničnih zona bili oduvijek ekonomski, društveno i obiteljski vezani za obližnju Sloveniju.

Ključne riječi: Varaždinska županija; hrvatsko-slovenski odnosi; Lepoglava; Donja Voća; Cestica; Bednja.

Rad je nastao u sklopu redovitog djelovanja Inštituta za narodnostna vprašanja iz Ljubljane, podružnica Rijeka. 
FILIP ŠKILJAN: Hrvatsko-slovenski odnosi na području granične zone Varaždinske županije

\section{HRVATSKO-SLOVENSKI ODNOSI NA PODRUČJU IVANEČKOG I VARAŽDINSKOG KRAJA U VRIJEME SOCIJALIZMA I U VRIJEME NOVOUSPOSTAVLJENIH DRŽAVA HRVATSKE I SLOVENIJE}

\section{UVOD}

Hrvatsko-slovenska granica od Podturena na sjeveru Međimurja do Savudrije na zapadnoj obali Istre je iznimno duga i iznosi 670 kilometara. Pogranični prostor Hrvatske i Slovenije od Međimurja do Istre društveno i geografski vrlo je raznolik. Usprkos tome vrlo je jasno vidljivo da postoje neke zajedničke osobine na čitavom pograničnom teritoriju. Svakodnevni život stanovništva uz granicu imao je u prošlosti i danas ima mnogo zajedničkih osobina. Život koji su vodili stanovnici današnjeg pograničnog dijela Varaždinske županije i susjednih Haloza bio je u socijalističkoj Jugoslaviji znatno drugačiji od života koji vode nakon uspostave hrvatsko-slovenske granice. Prostor granice u znanstvenom smislu do danas je vrlo rijetko promatran kroz iskaze pojedinaca koji žive u pograničnom prostoru, pa je stoga ovo istraživanje drugačije, budući da se temelji na doživljaju i iskustvima ljudi koji stanuju uz hrvatsko-slovensku granicu. Istraživanje je pokazalo da su stanovnici s jedne i s druge strane granice mnogo više orijentirani jedni na druge nego što su povezani sa svojim regionalnim središtima. Stoga je posve jasno da stanovništvo koje ne živi na tom određenom mikroprostoru teško može razumjeti izazove, probleme i procese s kojima se stanovništvo susreće. Na suživot i orijentiranost Slovenaca i Hrvata koji žive uz granicu jednih na druge utjecala je umnogome činjenica što su stanovnici Haloza i Maceljskog gorja živjeli u zajedničkoj državi između 1526. i 1991. (s kratkim prekidom od četiri godine u vrijeme Drugog svjetskog rata) bez ikakvih pregrada i granica. Granica je uvelike poremetila odnose Hrvata i Slovenaca s obje strane, a ti odnosi do danas, usprkos ulasku Hrvatske i Slovenije u Europsku uniju, nisu vraćeni u nekadašnje okvire.

Ovim se radom želi pokazati na koje su sve načine postojale veze između jednog i drugog prostora te koliko su te veze narušene nakon uspostave granice 1991. godine. Također se na temelju matičnih knjiga vjenčanih i umrlih hrvatskih župa uz hrvatsko-slovensku granicu u razdoblju od gotovo stotinu godina na području današnje Varaždinske županije želi ukazati na međusobnu povezanost hrvatskih i slovenskih krajeva.

$U$ istraživanju je primijenjen povijesni i etnološki pristup koji je vidljiv iz prikupljanja podataka iz matičnih knjiga umrlih i vjenčanih, odnosno iz metode usmene povijesti i prikupljanja priča kazivača. Upravo je svakodnevni život, ono što privlači sve više pozornost brojnih istraživača različitih struka: povjesničara, 
demografa, etnologa, antropologa i sociologa. Rezultati istraživanja su važni, među ostalim i zato što se gospodarske i društvene promjene unutar jedne mikroregije odražavaju daleko šire na društvenim i gospodarskim procesima. Istraživanje je najvećim dijelom zasnovano na metodi usmene povijesti, odnosno na polustruktiriranim intervjuima sa stanovnicima pograničnog dijela Varaždinske županije koji imaju veze sa slovenskim krajevima. Iskazi kazivača koji su sudjelovali u istraživanju spomenutog fenomena u pograničnim općinama Bednja, Donja Voća i Cestica te na području Grada Lepoglave govore o tim intenzivnim i kvalitetnim odnosima koji traju već stoljećima. U istraživanju je sudjelovalo 17 kazivačica i kazivača, od čega s područja općine Bednja dvoje, s područja Grada Lepoglave četvero, s područja Općine Donja Voća šest kazivača, a s područja Općine Cestica pet kazivača. ${ }^{2} \mathrm{Uz}$ istraživanje putem polustrukturiranih dubinskih intervjua pregledane su i matične knjige vjenčanih i umrlih župa Bednja, Višnjica, Voća, Nadkrižovljan, Križovljan i Cvetlin koje uglavnom potječu s prijelaza 19. na 20. stoljeće, odnosno iz prve polovine 20. stoljeća. Pitanja koja su postavljana kazivačima na području spomenutih općina i grada bila su ova:

1. Ime i prezime, mjesto i godina rođenja

2. U Vašem djetinjstvu i mladost, kakvi su bili odnosi Hrvata i Slovenaca s jedne i druge strane granice?

3. Da li je između Hrvata i Slovenaca bilo brakova?

4. Koliko su često Hrvati bili zaposleni u Sloveniji, odnosno Slovenci u Hrvatskoj?

5. Da li su se djeca školovala u Sloveniji, odnosno da li su se slovenska djeca školovala u Hrvatskoj?

6. Koliko je bilo dobro poznavanje slovenskog jezika? Koliko se jezik preko granice razlikuje od hrvatskog jezika koji se govori u Vašem mjestu?

7. Da li ste odlazili na sajmove, proštenja u Sloveniju, odnosno da li su Slovenci dolazili Vama?

8. Da li su Hrvati posjedovali zemlju u Sloveniji, odnosno da li su Slovenci posjedovali zemlju u Hrvatskoj?

9. Koliko ste u vrijeme socijalizma bili vezani na Sloveniju?

Istraživanja su poduzeta 2015. na području Općine Cestica te 2019. na području Općina Donja Voća, Bednja i na području Grada Lepoglave. Kazivači su bili ovi: Josip Križanec, 1949., Donja Višnjica, Goran Hočurščak, 1969., Varaždin (Donja Višnjica), Petar Bednjički, 1949., Bednjica, Blaž Milešić, 1950., Budinščak, Ivan Višinski, 1957.g., Gornja Višnjica, Đurđica Patrčević, 1960., Varaždin (Slivarsko), Vlatko Bukovec, 1947., Donja Voća, Barica Horvatić, 1945., Rijeka Voćanska, Vjekoslava Cvetko, 1947., Budinščak, Marija Križnjak, 1925., Rijeka Voćanska, Adam Pintarić, 1955., Podgorje Bednjansko, Mirko Bistrović, 1949., Bednja, Karel Benko, 1947., Gerlinci, Terezija Topolovec, 1949., Goričak (Zavrč), Ana Mumlek, Loče pri Poljčanah, Elizabeta Juričinec, Gornja Radgona, Marija Borak, Šmarje pri Jelšah. 
FILIP ŠKILJAN: Hrvatsko-slovenski odnosi na području granične zone Varaždinske županije

10. Koliko su se odnosi promijenili nakon uspostava neovisne Hrvatske i Slovenije? Da li Vam je to otežalo život?

\section{HRVATSKO-SLOVENSKI ODNOSI NA PODRUČJU GRADA LEPOGLAVE (VIŠNJICA I OKOLICA)}

Područje grada Lepoglave danas obuhvaća i nekoliko naselja uz samu hrvatsko-slovensku granicu. To su naselja Bednjica, Donja Višnjica, Gornja Višnjica, Jazbina Višnjička, Zlogonje i Zalužje. Kazivači s područja grada Lepoglave podrijetlom su iz Donje Višnjice, Bednjice i Gornje Višnjice. U razgovoru o hrvatskoslovenskim odnosima s područja Grada Lepoglave razgovarali su Josip Križanec iz Donje Višnjice, Goran Hočurščak iz Donje Višnjice, Petar Bednjički iz Bednjice i Ivan Višinski iz Gornje Višnjice. Međususjedski odnosi Hrvata i Slovenaca na ovom uskom području bili su tijekom socijalističke Jugoslavije vrlo intenzivni. Goran Hočurščak iz Višnjice rođen 1969. kazuje kako su u vrijeme socijalizma svi mještani Višnjice (Donje i Gornje) kao i okolnih naselja bili usko vezani uz mariborski i ptujski kraj. „Ptuj nam je bio najbliži, svega 18 kilometara. Svi smo gravitirali prema Mariboru. Čak je $80 \%$ ljudi ondje bilo zaposleno. “Činjenica je da je većina stanovnika Višnjice i okolice ondje odlazila i na školovanje u srednju školu. Kao i u Međimurju, i na području ivanečkog kraja Slovenci su učenicima osnovnih škola nudili stipendije i đačke domove kako bi dolazili na daljnje školovanje u Maribor. „Život nas je jednostavno nosio tamo. “Josip Križanec kazuje kako su Slovenci dobro prihvatili Zagorce i kako su ih htjeli školovati „da bolje živimo“. Ivan Višinski iz Gornje Višnjice govori kako su svi „mladi“ odlazili u Sloveniju (najčešće u Maribor i Ptuj, a ponekad i u Ljubljanu) nakon završene osnovne škole. „Učio sam zanat za automehaničara u Mariboru. U Maribor su dnevno putovali autobusi iz Višnjice. Maribor nam je bio najbliži veliki industrijski centar. Malotko je radio u Varaždinu i Krapini. U Mariboru su bile gigantske firme koje su zapošljavale sva pogranična naselja na hrvatskoj strani granice. Na autobusnom kolodvoru Maribor postojao je poseban peron broj 9 za putnike iz Višnjice. "Nekadašnjih desetak autobusa koji su vozili iz Višnjice u Maribor danas je zamijenila jedna linija koja veže Višnjicu, Ptuj i Maribor.

Najveći broj Hrvata iz sela uz samu granicu odlazili su u Sloveniju i ondje tražili partnerice. Na višnjičkom području iz sela Bednjica, Jazbina Višnjička, Zalužje i Zlogonje bilo je najviše nacionalno mješovitih brakova.

O međusobnim uskim vezama govori i činjenica da su „Hrvati odlazili za ozbiljnije liječničke preglede u Ptuj i u Cirkulane, a da su slovenska sela uz granicu 
imala vodovodne priključke iz Hrvatske“. Selo Zalužje je, na primjer, imalo struju iz Slovenije.

Hrvati i Slovenci su se vrlo često susretali i na proštenjima. „Na proščenjima smo kod Petera pekli pečenje. Međutim, kada su nam zabranili peći pečenje onda se i broj ljudi značajno smanjio. Nekada su dolazili Slovenci iz općine Cirkulane, iz općine Leskovec i općine Videm. " Proštenja su prema riječima sugovornika bili mali sajmovi. Posebno su važne lokacije za susretanje bile male kapelice koje su se nalazile na samoj granici između Hrvatske i Slovenije. Na Florijanu, kako kazivači nazivaju prijelaz između Hrvatske i Slovenije, kod kapelice Svetog Florijana na prvu nedjelju u svibnju održavalo se proštenje. Prema kazivanju Josipa Križanca iz Donje Višnjice „ujutro je misu služio župnik iz Cirkulana, iz Slovenije, a poslije podne župnik iz Hrvatske, iz Višnjice" pod čiju je jurisdikciju potpadala kapela Svetog Florijana. Prema riječima Ivana Višinskog iz Gornje Višnjice proštenja su bila i kod crkve u Cvetlinu (koja je također smještena na samoj hrvatsko-slovenskoj granici), a ondje su „osobito mnogo dolazili Slovenci“. I zemljišta su i Hrvati i Slovenci posjedovali i s jedne i s druge strane granice. Kazivač Ivan Višinski kazuje kako su mještani Višnjice imali zemljišta u Sloveniji na području Cirkulana.

Kazivači iz Višnjice se prisjećaju kako se situacija uz granicu Hrvatske i Slovenije uvelike promijenila uspostavom neovisnih država. „Firme giganti su počele propadati, a ljudi su počeli dobivati otkaze." Činjenica je da Hrvati nisu bili tjerani iz slovenskih poduzeća, već su se poduzeća gasila. Jedna od najvećih firmi TAM davala je i goleme otpremnine svojim radnicima, bili oni Hrvati ili Slovenci. Neki od kazivača su ostali u radnom odnosu u Sloveniji do mirovine. Međutim, dio njih su postali (tujci), odnosno strani državljani. Prema riječima Petra Bednjičkog iz Bednjice "ukoliko su Hrvat i Slovenac bili na burzi u Sloveniji, Slovenac je redovito dobivao posao".

Zbog komplikacija oko obrađivanja zemljišta i prenošenja plodova s jedne strane granice na drugu stranu, oni koji su imali zemljišta u Sloveniji uglavnom su svoje parcele prodali Slovencima. Prema riječima Ivana Višinskog „nakon prodaje zemljišta u Sloveniji pojedinci koji više nisu imali ondje zemlju morali su vratiti svoje pogranične kartice s kojima su mogli prelaziti i na neslužbenim prijelazima u Sloveniju“. Granični prijelazi na području Varaždinske županije relativno su brojni. Prema kazivanju sugovornika iz Višnjice jedan dio tih prijelaza je namijenjen samo za lokalno stanovništvo, a Cvetlin i Gornja Voća su namijenjeni za pogranični promet. Mještanima Višnjice smeta što nisu proglašeni za pograničnu zonu, pa zbog toga na svojem teritoriju nemaju međunarodni državni prijelaz. Pograničnih sporova na ovom teritoriju nikada nije bilo. Naime, ovdje je bila tzv. „Hitlerova granica“ (tako je zovu kazivači, op.a.), a prema kazivanju sugovornika 
granični kameni od vremena Marije Terezije su i danas vidljivi na pojedinim lokacijama u šumi i u nekim zaseocima (npr. zaseok Hercegi). Granica je u nekim slučajevima prolazila kroz dvorišta pojedinaca. Tako je Martin Kokol u Zalužju imao jedan dio dvorišta u Sloveniji, dok je drugi dio bio u Hrvatskoj. Prema kazivanju Ivana Višinskog, koji je godinama vozio školski autobus, postojali su problemi kada su vozači autobusa morali ući u Sloveniju da okrenu vozilo kako bi se vratili u Hrvatsku. Bilo je to upravo kod kapelice Svetog Florijana.

Nakon raspada zajedničke države značajno su se počeli razlikovati krajevi uz granični pojas. Naime, slovenska država je počela ulagati u pograničnu zonu Haloza, pa je taj dio Slovenije mnogo razvijeniji od ivanečkog kraja u Hrvatskoj. Danas se suradnja Slovenaca i Hrvata na višnjičkom i lepoglavskom području osobito očituje u zajedničkom radu dobrovoljnih vatrogasnih društava s jedne i $s$ druge strane granice. Prema riječima Hočurščaka kada je prije nekoliko godina uz samu granicu došlo do velikog šumskog požara zajedničkim snagama su požar gasila dobrovoljna vatrogasna društva iz Cirkulana, Voće, Višnjice i Cvetlina. Suradnja DVD-a uglavnom se svodi na obližnja pogranična vatrogasna društva. Međutim, u slučaju DVD-a Višnjica suradnja je vezana i za udaljeni Stari Trg pri Ložu (koji se nalazi nedaleko gorskokotarskog mjesta Prezida), pa su tako DVD Višnjica i DVD Stari Trg zbratimljena društva. Naime, ondje živi Višnjičanin Franjo Bukovec koji je uspio uspostaviti usku suradnju Grada Lepoglave i Višnjice te Starog Trga pri Ložu.

Jezične razlike između Hrvata i Slovenaca bile su na prostoru Varaždinske županije i susjednih Haloza ipak znatnije nego što je to bio slučaj na prostoru Međimurja i susjednog ljutomerskog kraja. Hočurščak se prisjeća kako su se Slovenci i Hrvati na prostoru Višnjice oduvijek dobro razumjeli, iako su Slovenci govorili slovenskim jezikom, a Hrvati svojim zagorskim dijalektom. Međutim, Hrvati su u rubnoj zoni uz granicu naučili odlično standardni slovenski jezik. „Znate, uvijek su nas Slovenci pitali iz kojeg smo dijela Slovenije. Slovenski sam naučio kao strani jezik, zbog školovanja i zbog posla“, kazuje Hočurščak. Višinski ističe da su mještani Zalužja uz granicu „osobito često miješali slovenske riječi“. 


\section{HRVATSKO-SLOVENSKI ODNOSI NA PODRUČJU OPĆINE DONJA VOĆA}

Područje Općine Donja Voća obuhvaća i pogranična naselja Jelovec Voćanski, Gornju Voću, Rijeku Voćansku i Budinščak. Na teritoriju Općine Donja Voća u razgovoru o hrvatsko-slovenskim odnosima sudjelovali su Đurđica Petrčević iz Slivarskog, Blaž Milešić iz Budinščaka, Vlatko Bukovec iz Donje Voće, Barica Horvatić iz Rijeke Voćanske, Vjekoslava Cvetko iz Budinšćaka i Marija Križnjak iz Rijeke Voćanske. Odnosi između Hrvata i Slovenaca na ovome području bili su jednako intenzivni kao i na području susjedne Višnjice.

Đurđica Patrčević se prisjeća da su se Hrvati i Slovenci najčešće „sretali u vrijeme sezonskih radova“. "Najčešće smo išli na rad u Sloveniju. Odlazili smo u obiranje hmelja. Često se odlazilo u Savinjsku dolinu i u okolicu Slovenskih Konjica. To je bio odličan izvor prihoda, a odlazila su i školska djeca." U Konjicama je bilo i voćnjaka (jabuke) tako da je Đurđica Patrčević bila ondje na radu čak dva mjeseca. U berbu grožđa se odlazilo u jesen u najbliža slovenska naselja poput Zavrča i drugih pograničnih sela. Ponekad se odlazilo i dalje, pa je Đurđica Patrčević odlazila i na branje jagoda u Šenčur pri Kranju. „Ondje sam ostala između 10 i 14 dana. Ti ljudi koji su uzimali radnike za hmelj ili jagode uvijek su uzimali iste iskušane radnike." I Barica Horvatić iz Rijeke Voćanske kazuje kako su mještani pograničnih sela bili izvor radne snage za Slovence. „Mi smo ondje odlazili kopati vinograde jer smo ondje mogli zaraditi i jedan put više nego u Hrvatskoj. Sjećam se da su nas otpelali u Vojnik, u Žalec i u Polzelu na hmel. Bili bismo ondje i po tri tjedna. Ondje bismo ujutro imali kavu i kruh, pa 'ajnpren' juhu i kruh do 13 sati, a potom za ručak meso i salatu. Znam da nas je bilo i po 25 ili 30 pri jednom gospodaru. Naša grupa je brojila 28 ljudi i svi su bili iz Budinščaka i Jelovca. Bila sam čak tri godine voditelj tih ljudi, pa sam dobivala dvije nadnice na dan. Znate, morala sam držati red, a oni (Slovenci, op.a.) su bili čisti i strogi. Bilo je radnika koji bi se napili i potukli, a toga nije smjelo biti." Marija Križnjak iz Rijeke Voćanske rođena 1925. godine prisjeća se da je prije Drugog svjetskog rata odlazila kod Slovenaca „kod Mohora“ (kapele na granici Hrvatske i Slovenije) gdje je okopavala, obrezivala i obirala vinograde. „Imam tri leta škole. Kada sam se navčila pisati i čitati više nisam trebala iti v školu. Išla sam tam pet ili šest let." Marija je išla i žeti hmelj. „Ǐ̌li smo vlakom do Vojnika i Žovneka. Bio je tu jedan kaj nas je vodio i koji je razglasil da se bo išlo. Išlo se na dva tjedna i moglo se dobro zaraditi.“

Susreti Slovenaca i Hrvata bili su i na lokalnim proštenjima. Đurđica Patrčević se prisjeća kako se odlazilo na proštenja na Ptujsku goru, na Svetu Anu kod Borla i u Ptuj. „Na sajmove i proščenja se odlazilo pješice.“ Najbliže proštenje odvijalo se na Svetom Mohoru, kapelici koja se nalazi uz samu granicu Hrvatske i 
Slovenije u Sloveniji. Misa se ondje obavljala na hrvatskom i na slovenskom. Vjekoslava Cvetko, koja vodi seoski turizam nedaleko kapele Svetog Mohora, kazuje kako je na Svetom Mohoru „nekada bilo puno ljudi, kako je bilo mesa, vina i muzike“, a kako "danas toga više nema“. „Danas dojde nekoliko njihovih i nekoliko naših i to je to."

Susreti su znali biti i u privatnim kućama gdje su Slovenci iz Borla i Zavrča te okolnih pograničnih mjesta znali navraćati u vrijeme kada se čehalo perje ili kada bi se ljuštile koščice za ulje, odnosno kada bi se u zimskim večerima radili drugi poslovi. Vjekoslava Cvetko iz Budinšćaka se prisjeća da su Slovenci dolazili u kuće. „Po kućama su se svirale tambure, pa bi naši poznanici Slovenci navečer dolazili do nas." I rodbinske veze su bile česte i brojne. Barica Horvatić se prisjeća da je bila „pet puta krsna kuma u Sloveniji“ što pokazuje koliko su uske bile veze pograničnih sela s jedne is druge strane.

Zanimljiva je konstatacija koja je potvrđena i u matičnim knjigama vjenčanih i umrlih da između Hrvata i Slovenaca na tome području nije bilo odviše mnogo nacionalno mješovitih brakova (u odnosu na nacionalno mješovite brakove u štrigovskom kraju na području ivanečkog pograničnog pojasa nacionalno mješovitih brakova je bilo znatno manje). Prema mišljenju Vlatka Bukovca familije su u pojedinim mjestima bile međusobno vezane (hrvatske i slovenske, op.a.). Posebno je to bilo vidljivo u pograničnoj zoni u Jelovcu Voćanskom, Rijeci Voćanskoj i u Budinščaku s jedne strane i u Zavrču s druge strane. Barica Horvatić smatra da je takvih brakova u pojedinim zaseocima znalo biti i "do 40 \%". Vjekoslava Cvetko kazuje da je „iz Budinšćaka bilo barem deset mješovitih brakova“. „Ipak, cure su odlazile više za snahe u Sloveniju, nego što je to bilo obrnuto." Kada bi se vjenčali Hrvat i Slovenka odlazili bi najčešće u velike gradove i ondje zasnivali obitelj. Tako je bilo u vrijeme socijalizma. Prema kazivanju Đurđice Patrčević ljudi su se ženili između sebe u selima u okolici Voće. Dakle, vjenčanja su se svodila na momke i djevojke koji su živjeli na području Donje Voće i okolice. Činjenica je, međutim, kao i u slučaju Višnjice, da je veliki broj ljudi bio zaposlen u Sloveniji. Svi mladi dečki su odlazili u zidare i tesare, a odlazili su rado jer su im u Sloveniji bili ponuđeni smještaji. Većina muškaraca iz okolice Donje Voće bili su zaposleni u Sloveniji u građevinskim poduzećima. „Sjećam se da su petkom putovala dva autobusa za Voću iz Slovenije i da si jedva mogao stajati u autobusu od gužve. Većina ljudi je migrirala na tjednoj bazi tako da su djecu i obitelji imali u Hrvatskoj, a da su oni radili u Sloveniji. Tamo su često stanovali u radničkim barakama.", kazuje Đurđica Patrčević. Vjekoslava Cvetko se prisjeća da je njezin otac radio 35 godina kao zidar u Sloveniji te da je jednom mjesečno dolazio kući. „Žene nisu toliko odlazile za Sloveniju, jedino kao kuharice.. Vjekoslava Cvetko radila je šest 
mjeseci kao kuharica u Sloveniji. Prema riječima Barice Horvatić žene voćanskog kraja su najčešće „bile domaćice koje su hranile krave, svinje, okopavale vrtove, kuruzu, vinograde jer se sve to moglo dobro prodati. Ako si imao dvadeset ili trideset pajceka mogao si zaraditi više nego radnik u Ivancu. Sve se to prodavalo u zadruge. U Klenovnik u bolnicu smo prodavali ciklu, piceke i crvenu mrkvu, a u dvor Trakoštan (sic!) vino i u Krapinske Toplice, dok smo med prodavali u Bajnski dvor u psihijatriju kod Čalinca." Međutim Đurđica Patrčević se prisjeća da je završila za geološkog tehničara u Varaždinu te da je otišla nakon završene srednje škole u Ljubljanu. „Ondje sam se zaposlila i radila 39 godina. Putovala sam svaki drugi vikend sim, u Zagorje. Sve dopuste i praznike sam provodila u Slivarskom, doma. Tu je bio za mene život, tamo sam samo radila. U vrijeme bivše države postojala je direktna linija koja je vezala Ljubljanu i Varaždin, a iz Maribora je za Varaždin išao svaki sat autobus." I Vlatko Bukovec je završio srednju školu u Ljubljani. „Otišao sam 1961. za učenika u Ljubljanu. Ondje su izučavali za zidare, tesare, bravare, strojare. Gore sam radio između 1961. i 1967. Sigurno nas je preko 40 \% iz Donje Voće bilo zaposleno u Sloveniji." I Barica Horvatić kazuje kako je malotko radio u Varaždinu i u Ivancu. „Svi muški su išli u Sloveniju. Bili smo siromašni. Malotko je imao novaca za srednju školu, a Slovenci su nudili besplatno školovanje i smještaj te kasnije zaposlenje. Iz Voće je putovalo na dnevnoj bazi i po tri autobusa ljudi za Maribor i Ptuj." Jedan dio naselja Jelovec Voćanski i Budinšćak su imali priključke za struju iz Slovenije. Prema riječima Barice Horvatić djeca iz Florijana i dijela Zlogonja kod Višnjice (u Hrvatskoj) odlazila su u Cirkulane u školu, a zaseok Žihri odlazio je u Zavrč u školu. Liječnicima se odlazilo u Ptuj, Cirkulane, Zavrč i Borl.

Nakon uspostave dvaju država veliki broj zaposlenih u slovenskim poduzećima ostao je bez posla. Brojni su ostali bez posla jer nisu dobili dozvole za rad. „U Sloveniji su ostali jedino oni koji su dobili državljanstvo i koji su gore osnovali obitelj." Đurđica Patrčević se prisjeća koliko se zakompliciralo putovanje do njezinog rodnog mjesta nakon uspostave dvaju država. „Danas ne postoji niti jedna direktna linija iz Ljubljane za Varaždin. Postoji linija koja vozi do granice u Križovljanu, ili postoji vlak do Ormoža. Znala sam pješačiti i po nekoliko kilometara da bih došla do vlaka ili do autobusa na hrvatskoj strani. Postoji samo jedan direktan vlak koji vozi iz Ormoža za Ljubljanu, a kod ostalih moram i po dva puta presjedati." Patrčević se prisjeća koliko je teško utjecalo postavljanje granice na lokalno stanovništvo: „Dok nije bilo granice nitko živ nije ni znao gdje je granica. To je bilo potpuno nevažno. Šok je bio golem kada je granica uspostavljena i kada su nam pregledavali torbe, ali smo se s vremenom navikli." Barica Horvatić kazuje kako su „svi bili povrijeđeni uspostavom granice“. „Ljudi su imali kuću u 
Hrvatskoj, a stoku u Sloveniji i nitko nikoga do uspostave granice nije kontrolirao. Osim toga, prorijedili su se posjeti njih nama i nas njima. Bili smo kıo braća, međusobno smo si pomagali i nitko nikoga nije podcjenjivao, a sada smo bili razdvojeni granicom. U Sloveniju smo dolazili kupovati, ali nakon uspostave granice smo prestali. Onda su otvorili mali prijelaz Gornja Voća-Lapornik. Do tada smo morali ići na Dubravu Križovljansku. Nisu svi dobili pogranične karte. Morali su imati preko zemlju da mogu dobiti kartu. Bez karte nisu mogli svugdje prek > granice jer je gore bila policija. Naši i danas imaju preko zemlju, pa smo prije koju godinu kada su htjeli podići žicu uspjeli to spriječiti." Zanimljivo je iskustvo Vjekoslave Cvetko koja vodi Seoski turizam Cvetko na samoj hrvatsko-slovenskoj granici. Prema njezinom smatranju turizam koji se nalazi na samom vrhu brijega, na hrvatsko-slovenskoj granici, bio je zanimljiv i Slovencima. „Hteli su nas znate Slovenci da potpadnemo pod Sloveniju, ali moj muž nije htio. Došla je slovenska policija iz Maribora i rekli su nam da samo stavimo njihov telefon i da ćemo postati dio Slovenije, da ćemo dobiti njihovo državljanstvo."

Slovence i Hrvate s obje strane granice u Voći ujedinila je 2000-tih borba protiv deponija atomskog otpada u Drenovcu, tik uz hrvatsko-slovensku granicu, gdje je slovenska država željela napraviti odlagalište.

Odnos prema Hrvatima s toga područja koji su zaposleni u Sloveniji također je specifičan. Ni organiziranje Hrvata iz toga kraja u većim slovenskim gradovima nije na razini. Zanimljivo je rezoniranje Đurđice Patrčević koja tvrdi da se „Hrvati iz Hrvatskog zagorja u Sloveniji i u Ljubljani malo drže zajedno“. „Mi se ne držimo skupa u Ljubljani, mi smo sličniji u tome Slovencima. Nekada se i ne poznamo kada se vidimo gore, a mnogi među sobom govore slovenski. Srbi, Bosanci i Hercegovci se puno bolje drže skupa." Đurđici je smetalo kada bi je Slovenci zvali južnjakinjom, Bosankom. „Znate, ja sam im govorila da ja nisam rođena južnije od Ljubljane nego sjevernije. Međutim, njima su svi preko Kupe bili Južnjaki, a nas Zagorce su trpali u isti koš sa Međimurcima, pa su mi govorili da sam iz okolice Čakovca. Hiljadu puta sam im govorila da sam iz Varaždina, a oni su mi opet govorili da sam iz Čakovca. Nikada nisam dobro naučila slovenski, uvijek se osjećao naš zagorski dijalekt. Međutim, Međimurci su najbolje učili slovenski. Bila je razlika u tome između nas Zagoraca i njih (Međimuraca, op.a.)." Prema riječima Vlatka Bukovca i danas pojedini školarci odlaze na školovanje u Sloveniju. „Iz Gornje Voće mladi odlaze u škole u Ptuj. Njihovi roditelji tamo rade, pa će oni tamo raditi."

Jezik se razlikovao i prema riječima kazivača bio je dosta različit od slovenskog dijalekta preko granice. „Međutim, mi smo razmeli sve kaj su oni govorili, a razmeli smo i književni slovenski jezik“, govori Đurđica Patrčević. Vlatko Bukovec 
kazuje kako je „jezik bio vrlo sličan“. "Melodičnost naših jezika je povezana, a i slična je muzika koja se pjeva i svira s jedne i s druge strane granice. Znali smo odakle je koji Slovenac preko granice. A i njih kada bi pitali odakle je koji od nas znali su pogoditi prema našem dijalektu selo iz kojeg potječe." Barica Horvatić kazuje kako su govor „zmešali“. „Bila je to polovica hrvatski, a polovica slovenski.“ I Slovenci su, prema kazivanju Barice Horvatić, miješali voćanski i slovenski. Vjekoslava Cvetko kazuje da je jezik dosta sličan. „Znali su me ljudi pitati da li sam Slovenka budući da govorim dijalekt koji je sličan slovenskom jeziku."

\section{HRVATSKO-SLOVENSKI ODNOSI NA PODRUČJU OPĆINE BEDNJA}

Područje Općine Bednja u svojem se jednom dijelu poklapa s hrvatsko-slovenskom granicom. Naselja koja se nalaze tik uz hrvatsko-slovensku granicu i gdje su hrvatsko-slovenski kontakti najintenzivniji su Cvetlin, Jamno, Jazbina Cvetlinska i Brezova Gora. Na području općine Bednja iskaze su dali Adam Pintarić iz Podgorja Bednjanskog i Mirko Bistrović iz Bednje.

Kao i u Donjoj Voći i u Višnjici kazivači iz Bednje i okolice prisjećaju se činjenice da je većina stanovnika nekadašnje općine Ivanec bila zaposlena na području Maribora, Celja, Kidričeva i Ptuja. Mirko Bistrović posebno ističe sličnosti u tradiciji i običajima. "Naime, i s jedne i s druge strane granice jelo se na isti način, slavili su se na isti način blagdani, a i način života je bio isti ili vrlo sličan. Kod njih je ono što je bila kisela obara bila naša ajnpren juha." Međunacionalni odnosi bili su posebno bliski u mjestu Cvetlin koje se nalazi na nekoliko kilometara od granice, a čija je župna crkva na samoj štajersko-hrvatskoj granici. Prema riječima Mirka Bistrovića u Cvetlinu „i danas živi 17 slovenskih snaha“. Veliki broj mješovitih brakova nastao je i izvan Općine Bednja u gradovima u koje su Bednjanci odselili. Tako su mnogi brakovi zasnovani u Mariboru i Ptuju gdje su Bednjanci radili tijekom socijalizma. Cvetlin već trideset godina održava manifestaciju Cvetlinski zvon na kojoj su oduvijek prisutni i Slovenci iz najbližih sela i općina u Štajerskoj. $\mathrm{U}$ vrijeme socijalizma najveći broj Bednjanaca rodio se na području Slovenije u Ptuju, odnosno u rodilištu koje je bilo najbliže (bliže i od Varaždina i od Krapine, op.a.).

Susreti Slovenaca i Hrvata na području Bednje i okolice bili su osobito česti na proštenjima. „Kod nas postoje dvije kapelice: Jaguštin i Marija Magdalena. Kod Jaguština na samoj granici je misno slavlje na dva jezika - hrvatskom i slovenskom na zadnju nedjelju u kolovozu." Prije uspostavljanja granice svaki vikend su u dvorcu i hotelu ispod dvorca Trakošćan bile organizirane zabave. 
Prema riječima Mirka Bistrovića granica je 1991. godine „bila šok“. Adam Pintarić iz Podgorja Bednjanskog voditelj je dvora Trakošćan. „Nakon uspostave neovisnih država broj turista iz Slovenije naglo se smanjio. Izleti koji bili organizirani iz Slovenije prestali su. Mi smo nekada imali $10 \%$ turista iz Slovenije i ta je brojka nestala. Na rampi na granici gubilo se vrijeme, pa su turisti odustajali od posjeta Trakošćanu. Broj nekadašnjih turista nikada se nije vratio na staru poziciju. Tek nekoliko grupa iz Rogaške Slatine i Olimja dolazile su i nakon devedesetih u Trakošćan." Problemi su se javili i u činjenici što su pojedina gospodarstva ostala podijeljena između Hrvatske i Slovenije. „Ljudi su imali gospodarske zgrade u Sloveniji, a kuće u Hrvatskoj." Prelazak preko granice na neslužbenim prijelazima bio je omogućen samo onima koji su imali posjedovne listove za slovensko zemljište. Oni su imali ključeve na rampama i ondje su prelazili preko u Sloveniju. Zabave koje su se nekada odvijale u dvorcu i hotelu nestale su uspostavom granice. U trakošćanski hotel vikendima više nije dolazilo ni hrvatsko stanovništvo. Ipak, hrvatsko-slovenski odnosi uspostavom dvaju država nisu nestali. Treba ukazati na činjenicu da u Bednji i danas djeluje Hrvatsko-slovensko društvo prijateljstva čiji je osnivač bio Mirko Bistrović. „Hrvatsko-slovensko društvo prijateljstva osnovano je 2007. godine i ima oko 100 članova. Preko DVD-a i gospodarskih djelatnosti surađujemo s Općinom Videm i Općinom Ptuj. Nekoliko naših ljudi su otvorili poduzeća u Sloveniji. Hrvatsko-slovensko društvo prijateljstva redovito organizira izložbe, a organizirali smo i Školu nogometa i kulture u koju je bilo uključeno 250 djece iz Videma i Bednje. Postoji i uska suradnja umirovljenika, a susreti vatrogasaca se održavaju u Bednji i u Leskovcu. Imamo također i usku suradnju s DVD-om Černelovci kod Murske Sobote."

\section{HRVATSKO-SLOVENSKI ODNOSI NA PODRUČJU OPĆINE CESTICA}

Općina Cestica općina je s najvećim brojem pripadnika slovenske nacionalne manjine u Varaždinskoj županiji (177 pripadnika 2011., a 189 pripadnika 2001.). Pogranična naselja Općine Cestica su Vratno Otok, Dubrava Križovljanska, Babinec, Falinić Breg, Brezje Dravsko, Veliki Lovrečan, Virje Otok, Virje Križovljansko, Kolarovec, Selci Križovljanski, Jarki i Križanče. Najveći dio slovenskog stanovništva u Cestici i okolici potječe iz obližnje Štajerske, odnosno iz ormoškog područja. Cestica i nekoliko naselja koja su uključena u ovu općinu u vrijeme socijalizma i zajedničke države gravitirali su prema Sloveniji. Kao i u naseljima u nekadašnjoj Općini Ivanec, u Cestici i okolici velik je broj stanovnika radio u Sloveniji. Budući 
da je veći broj Slovenki i Slovenaca doselio na ovo područje kazivači su u ovoj općini bili pripadnici slovenske nacionalne manjine. ${ }^{3}$

Putevi dolaska Slovenki u cestičko područje vrlo su raznoliki. Ana Mumlek rođena je u selu Loče pri Poljčanah. Oko 1969. godine u njezino je selo došlo oko 100 radnika iz okolice Varaždina koji su gradili dalekovod. Neke od ljubavnih veza koje su tada započete, završile su brakovima između Slovenki i Hrvata. Ana Mumlek ističe kako je država podržavala takve brakove koji su širili ideju „bratstva i jedinstva“. Ana se udala za svojeg „zagorskog“ izabranika tek 1981. godine kada je njegova supruga preminula. Došavši u Babinec pokraj Cestice uložila je sav svoj imetak u stambeno-poslovnu zgradu, gdje su imali gostionicu, trgovinu i autoprijevoz. Kazuje kako promjena sredine nije bila „čist lahka“, ali da joj nije bilo druge jer se nije mogla vratiti u Štajersku. Postojale su i manje razlike između Štajerske i varaždinske Podravine u mentalitetu, kazuje Ana Mumlek. „Ovdje je muž bio glava obitelji, a gore su žene bile malo samostalnije." O sličnosti mentaliteta pak govori kazivačica Marija Borak naglašavajući da su veće razlike u mentalitetu između Štajeraca stanovnika Gorenjske, nego između Štajeraca i stanovnika ovog dijela varaždinske Podravine. Ana Mumlek ističe da kao Slovenka nikad nije imala problema, a da su za Cestičane svi Slovenci uvijek bili Štajerci ili Štajerke, bez obzira na činjenicu da su neki od njih bili podrijetlom iz Gorenjske ili Prekomurja. „Nikada nisam znala hrvatsku gramatiku, ali nikome nije bilo krivo ako bih ja govorila pola-pola. Govorila sam prosto seljački i svi su me razumjeli. I danas, nakon toliko godina života u Hrvatskoj, novac brojim na slovenskom i molim se na slovenskom jeziku." Razgovori kod kuće vođeni su na nekome miješanom jeziku, uglavnom više slovenskom, a manje hrvatskom, kako kazuje Ana Mumlek. I druga kazivačica, Elizabeta Juričinec iz okolice Gornje Radgone, koja je supruga upoznala početkom šezdesetih godina dvadesetog stoljeća u Ljubljani, također je imala problem s poznavanjem jezika kada se doselila u Radovec. Nijedna kazivačica nije zbog svog nepoznavanja hrvatskog jezika imala bilo kakvih problema u cestičkoj sredini budući da je većina stanovništva u Cestici i okolici radila u Mariboru, Ptuju i Ormožu pa su slovenski razumjeli, a lokalni govor također se ne razlikuje mnogo od slovenskog. Za Mariju Borak hrvatski nije predstavljao problem budući da je "učila hrvatsko-srpski jezik" u školi u Šmarju pri Jelšah.

U Cestici i okolici oduvijek je bio vrlo prisutan tolerantan internacionalni duh. Činjenica da se na nekim grobljima župe Križovljan, primjerice na groblju kod Svetog Lovre koje se nalazi unutar Općine Cestica, pokojnici pokapaju uz 
polaganje slovenske i hrvatske zastave u grob te da se $u$ istomu mjestu služi misa na slovenskom jeziku, pokazuje stoljetni suživot Hrvata i Slovenaca na ovom prostoru. I obrnuta priča o pokapanju Hrvata iz Dubrave Križovljanske na groblju u Zavrču te služenje misa na hrvatskom jednom mjesečno u Zavrču, ukazuje na istu pojavu.

Priča Terezije Topolovec iz Zavrča rođene 1949. godine ukazuje kako su nastajali brakovi na granici. Terezija je živjela u malenom selu Goričak nasuprot Lovrečanu, „uz meju“ gdje je granicu činila šuma. „Samo su stare babice znale gdje je granica." Prvog supruga, koji je podrijetlom bio iz Brezja u Hrvatskoj, upoznala je u Zavrču u kinu, mjestu gdje su se susretali mladi. „Osim kina u Zavrču, u široj okolici nije bilo ničega, nikakvog mjesta gdje bi mladi mogli izaći van i družiti se." Terezija kazuje kako se oduvijek znalo tko je tko, ali da su svi živjeli u „sožitju“ i da „nije bilo mržnje“. Za jezik ističe kako se uz samu granicu govorio jedan jezik, lokalni dijalekt koji se nije međusobno razlikovao.

Priča kazivača Karela Benka iz Cestice ukazuje na jedan od oblika dolaska Slovenaca na područje Cestice. Benko je rođen u selu Gerlinci u Prekomurju 1947. godine. U selu je ostao do 1961. kada je otišao u Osijek u gimnaziju. Nakon završene škole i fakulteta otišao je na rad u Njemačku gdje je upoznao suprugu podrijetlom iz Gornjeg Vratna pokraj Varaždina. Godine 1968. vjenčali su se i 1970. godine kupili gradilište „preko mosta“ u Nadkrižovljanu.

Benko kazuje kako je iz Cestice svakodnevno išlo i po desetak autobusa prema Mariboru, Ptuju, Ormožu i Murskoj Soboti budući da je većina stanovnika do 1995. radila u slovenskim poduzećima. Prema kazivanju Ane Mumlek, u škole cestičkog područja dolazili su agitatori iz slovenskih poduzeća i nudili izvrsne uvjete školovanja ukoliko nastave školovanje u Sloveniji. „Sve su imali besplatno u Sloveniji, čak i stan i hranu." Benko ističe i činjenicu kako su djeca iz Dubrave Križovljanske i iz Virja za vrijeme Jugoslavije odlazila u školu u Sloveniju jer im je bila bliža nego hrvatske škole, a da to čine i danas.

Slovenci u Cestici iznimno su dobro uklopljeni u sredinu u kojoj je većina stanovnika radila u Sloveniji i u kojoj postoji svakodnevni doticaj sa Slovenijom. Zbog mješovitih brakova i Hrvati uče slovenski jezik, a prema riječima Benka: „kod nas nitko ne kaže da smo manjina“, nego "ti si naš“. Slovenski igrokazi u Cestici mogu se igrati bez prijevoda, dok je tako nešto u osamnaest kilometara udaljenom Varaždinu teže ostvarivo. 


\section{MATIČNE KNJIGE UMRLIH I VJENČANIH KAO IZVOR ZA PRIKUPLJANJE PODATAKA O INTENZITETU HRVATSKO-SLOVENSKIH ODNOSA ${ }^{4}$}

\section{ŽUPA NADKRIŽOVLJAN I KRIŽOVLJAN}

Ime Križovljan župa nije mogla dobiti prije 1574. godine kada je ukinuta istoimena župa kod Martijanca istočno od Varaždina. Prvotnu kapelu u Zavračju, kako se tada zvao Lovrečan podigao je u 16. stoljeću Ivan II. Drašković. Uskoro potom spominje se u Statusima župe njegova banska krčma u Dubravi Križovljanskoj te skela i mlinovi kod Lovrečana. Kapela je preuređena u čast Svetog Lovre 1678. , a današnji je oblik dobila 1738. godine. Osim Dubrave Križovljanske koja je dodijeljena župi Zavrč u današnju Općinu Cestica potpada i cjelokupno područje župe Natkrižovljan. U mjestu Natkrižovljan bila je podignuta drvena kapelica Svetoga Josipa, a zatim zidana kapela Svete Barbare koja današnji oblik dobiva dogradnjama 1775. godine. Ta filijalna kapela župe Križovljan u jozefinističkoj reformi 1789. godine proglašena je župnom crkvom. ${ }^{5}$

Iz pregleda matične knjige umrlih i vjenčanih župa Natkrižovljan i Križovljan moguće je ustanoviti da je najveći broj mješovitih brakova u prvoj polovici 20. stoljeća bio u župi Križovljan te da su brakovi sklapani u uskom pograničnom području, odnosno u zoni nekoliko kilometara od granice s jedne i druge strane. Tek poneki doseljenik iz Slovenije bio je iz udaljenijeg područja (Ljubljana, Slovenska Bistrica, Hoče pri Mariboru i Vrhnika). Na području župe Nadkrižovljan (koja je obuhvaćala manje područje od župe Križovljan) vidljivo je da su brakovi također sklapani sa susjednom Štajerskom te da župnik u Matičnoj knjizi umrlih nije bilježio točno mjesto rođenja već samo pokrajinu u kojoj se pokojnik rodio (Štajerska), dok je kod Matične knjige vjenčanih situacija bila nešto bolja, pa je župnik zabilježio i naselja iz kojih su mladoženja ili mlada potjecali.

4 Matične knjige svih ovih župa nalaze se mikrofilmirane u Hrvatskom državnom arhivu, a originalne knjige se nalaze u Državnom arhivu u Varaždinu.

5 O župama Križovljan i Nadkrižovljan vidi u: Ivan KOŠıć, Povijest župe Križovljan, Varteks, Tiskara, Varaždin, 1987. 
Tablica I. Matična knjiga umrlih župe Nadkrižovljan 1902.-1929. i 1930.-1949. ${ }^{6}$

\begin{tabular}{|l|l|}
\hline Mjesto smrti & Mjesto podrijetla i godina smrti \\
\hline Selci & $\begin{array}{l}\text { Zavrč (1904.), Štajerska (1920.), Hrastovec (1921.), } \\
\text { Zavrč (1927.) }\end{array}$ \\
\hline Vinica Brieg & $\begin{array}{l}\text { Sveta Barbara u Halozama (1905.), Štajerska (1905.), } \\
\text { Štajerska (1905.) }\end{array}$ \\
\hline Križovljan Brieg & $\begin{array}{l}\text { Sveti Juraj u Štajerskoj (1905.), Sveti Juraj na Štajeru } \\
\text { (1906.), na Štajeru (1906.), Marburg (1917.) }\end{array}$ \\
\hline Križanci & $\begin{array}{l}\text { Goričak (1909.), Štajerska (1911.), Štajerska (1920.), } \\
\text { Hrastovec (1934.), Turski Vrh (1935.) }\end{array}$ \\
\hline Falinić Brieg & Štajerska (1914.) \\
\hline Križanbreg & Štajerska (1926.) \\
\hline Nadkrižovljan & Štajerska (1928.) \\
\hline
\end{tabular}

Tablica II. Matična knjiga vjenčanih župe Nadkrižovljan 1902.-1929. i 1930.-1949. ${ }^{7}$

\begin{tabular}{|l|l|}
\hline Mjesto stanovanja & Mjesto rođenja i godina vjenčanja \\
\hline Jarki & $\begin{array}{l}\text { Goričak (1908.), Drenovec (1922.), Goričak (1923.), } \\
\text { Turski Vrh (1940.) }\end{array}$ \\
\hline Gorušenjak & Štajerska (1911.) \\
\hline Križovljan Brieg & Goričak (1912.) \\
\hline Falinić Brieg & Vodranci (1913.) \\
\hline Selci & Ormož (1914.), Turski Vrh (1915.), Zavrč (1939.) \\
\hline Nadkrižovljan & Radohova Vas (1929.) \\
\hline Križovec & Goričak (1939.) \\
\hline Vinicabreg & Goričak (1941.) \\
\hline
\end{tabular}

6 Hrvatski državni arhiv (dalje HDA), Matična knjiga umrlih (dalje MKU) Nadkrižovljan 1902.-1929., 1930.-1949.

7 HDA, Matična knjiga vjenčanih (dalje MKV) Nadkrižovljan 1902.-1929., 1930.-1949. 
Tablica III. Matična knjiga umrlih župe Križovljan 1901.-1934. i 1935.-1949. ${ }^{8}$

\begin{tabular}{|l|l|}
\hline Mjesto smrti & Mjesto rođenja i godina smrti \\
\hline Križovljan & $\begin{array}{l}\text { Gorenski Vrh (Zavrč) (1903.), Zavrč (1920.), Slovenska } \\
\text { Bistrica (1927.), Turski Vrh (1934.) }\end{array}$ \\
\hline Babinec & Sveti Leonard (1904.), Ormož (1935.) \\
\hline Vratno & $\begin{array}{l}\text { Središče (1906.), Kranjska (blizu Ljubljane (1913.), } \\
\text { Slivnica (1924.) }\end{array}$ \\
\hline Grad Križovljan & $\begin{array}{l}\text { Sveta Nedelja (1915.), Cvetkovci (1923.), Ormož } \\
\text { (1939.) }\end{array}$ \\
\hline Virje Otok & $\begin{array}{l}\text { Gradec (Graz) (1915.), Lukavec na Štajeru (1917.), } \\
\text { Rjavec (1918.) }\end{array}$ \\
\hline Virje & Sveti Wolfgang (1916.), Ormož (1929.) \\
\hline Lovrečan & $\begin{array}{l}\text { Brezovec (1921.), Dubrava Brieg (Zavrč) (1921.), } \\
\text { Velika Nedelja (1924.), Ormož (1930.), Zavrč (1932.), } \\
\text { Hrastovec (1936.) }\end{array}$ \\
\hline Cestica & Župa Sveti Tomaž u Štajeru (1923.) \\
\hline Radovec & Hrastovec (1925.), Veliki Vrh (1933.) \\
\hline Brezje & Sveti Marko pri Ptuju (1928.) \\
\hline
\end{tabular}

Tablica IV. Matična knjiga vjenčanih župe Križovljan 1912.-1948. ${ }^{9}$

\begin{tabular}{|l|l|}
\hline Mjesto življenja & $\begin{array}{l}\text { Mjesto rođenja jednog od mladenaca i godina } \\
\text { vjenčanja }\end{array}$ \\
\hline Falinić Brieg & Goričak (1918.), Dubrava Brieg (1922.) \\
\hline Otok & Senešci (Velika Nedjelja) (1919.), Cvetkovci (1920.) \\
\hline Lovrečan Brieg & $\begin{array}{l}\text { Turski Vrh (1919.), Vrhnika (1928.), Goričak (1929.) } \\
\text { (otišli u Goričak), župa Zavrče (1933.), Turski Vrh } \\
\text { (1935.) (otišli u Turski Vrh) }\end{array}$ \\
\hline Brezje & Središče (1919.), Hajndl (1927.) \\
\hline Križovljan & Pavlovec (Ormož) (1920.) \\
\hline
\end{tabular}

HDA, MKU Križovljan 1901.-1934., 1935.-1949.

9 HDA, MKV Križovljan 1912.-1948. 
FILIP ŠKILJAN: Hrvatsko-slovenski odnosi na području granične zone Varaždinske županije

\begin{tabular}{|l|l|}
\hline Vratno & $\begin{array}{l}\text { Razvanje (Hoče pri Mariboru) (1920.), Veliki Vrh } \\
\text { (1924.), Mota kraj Ljutomera (1930.) (otišli u Motu) }\end{array}$ \\
\hline Križovljan Grad & $\begin{array}{l}\text { Svetinje (Velika Nedjelja) (1920.), Slovenska Bistrica } \\
\text { (1923.), Zavrč 2X(1932.), Maribor (1936.) }\end{array}$ \\
\hline Radovec & $\begin{array}{l}\text { Dubrava (župa Zavrč) (1922.), Libanje (1928.) (otišli u } \\
\text { Libanje), Hajndl (1930.) (otišli u Hajndl) }\end{array}$ \\
\hline Babinec & $\begin{array}{l}\text { Rogatec (1923.), Runeč (Velika Nedjelja) (1926.), } \\
\text { Moškanjci (1928.), Goričak (1939.) }\end{array}$ \\
\hline Kolarovec & $\begin{array}{l}\text { Svetinje kod Ormoža (1929.), župa Ptuj (1932.) (otišli } \\
\text { u župu Ptuj), župa Velika Nedjelja (1933.) (otišli u } \\
\text { Sveti Lenart) }\end{array}$ \\
\hline Cestica & Pavlovci (Ormož) (1928.) \\
\hline Virje & Libanje (1936.) (otišli u Libanje) \\
\hline
\end{tabular}

\section{ŽUPA BEDNJA}

Župa Bednja se spominje već 1334 . godine pod imenom „ecclesia de Tracustain“, Nekada je župa bila mnogo veća nego što je to danas. Unutar župe su se nalazila naselja koja danas potpadaju pod župe Višnjica, Cvetlin i Lepoglava. Patronom župe Bednja bila je porodica Drašković, a župna crkva u Bednji bila je posvećena Blaženoj Djevici Mariji te je bila sazidana 1639. godine. Broj stanovništva se unutar župe mijenjao tako da je župa 1786. godine imala 5323 stanovnika, 1805. 4168, a 1822. godine 3639 stanovnika. Župa je do 1867. godine imala samo jedno groblje u Bednji, a potom je otvoreno i groblje u Vrbnom. U sredini crkve imala je obitelj Drašković, inače vlasnici dvorca Trakošćan, svoju grobnicu. U župi se nalazila i kapela Svetoga Duha na čijem je mjestu danas planinarski dom Pusti duh. Kapela Svetoga Josipa na brdu Hum se spominje u 17. stoljeću, dok je kapela Svetog Jurja u Purgi postojala već sredinom 15. stoljeća. Kapela Svetog Ivana na Gorici kod Lepoglave oslikana je Rangerovim slikama, a kapela Sveta Tri Kralja nalazi se nedaleko kapele Svetog Duha. Kapela Svetog Križa pod dvorcem Trakošćan podignuta je sredinom 18. stoljeća. U župi su postojale i kapelice Svetog Roka u Bednji, kapela Svetog Urbana u Šaši i kapela srca Isusovog u Vrbnom. Posebno treba spomenuti kapelu Svetog Petra „in Czerin“ koja je stajala uz hrvatsko-slovensku granicu uz cestu koja iz Trakošćana vodi prema Ptuju. Ta je kapelica 1792. godine postala župnom crkvom župe Cvetlin. ${ }^{10}$

10 Vidi o župi Bednja u: Vjekoslav NORŠıĆ, „Bednja“, Tkalčić, 14, Zagreb, 2010., 195-240. 
U matičnim knjigama župe Bednja vidljivo je da je bilo ubilježeno vrlo malo osoba podrijetlom iz Slovenije. Većina je osoba bila podrijetlom iz Štajerske, ali ne iz krajeva u blizini Bednje, već uglavnom iz udaljenijih područja (Središče, Slovenska Bistrica, Ljutomer). Razlog tome leži i u činjenici što se župa u Bednji nije naslanjala direktno na granicu, već na župu Cvetlin koja je bila između Štajerske i župe Bednja. Stoga su i međusobni kontakti jednih i drugih bili rjeđi od župa koje su bile uz samu granicu.

Tablica V. Matična knjiga umrlih župe Bednja 1910.-1922. ${ }^{11}$

\begin{tabular}{|l|l|}
\hline Mjesto smrti & Mjesto rođenja i godina smrti \\
\hline Bednja & Kromsfeld (1914.) \\
\hline Vrhovec & Sveta Margeta (Štajerska) (1915.) \\
\hline Rinkovec & Celovec (1917.) \\
\hline Prebukovje & Središče (1923.) \\
\hline Gorenec Mali & $\begin{array}{l}\text { Velika Ves (Slovenska Bistrica) (1934.), javna bolnica u } \\
\text { Mariboru (1935.) }\end{array}$ \\
\hline Ježovec & Središče (1935.), župa Zavrč (1941.) \\
\hline
\end{tabular}

Tablica VI. Matična knjiga vjenčanih župe Bednja 1890.-1934. i 1935.-1947. ${ }^{12}$

\begin{tabular}{|l|l|}
\hline Mjesto življenja & Mjesto rođenja i godina vjenčanja \\
\hline Meljan & Majberg (1892.), Majberg (1902.) \\
\hline Bednja & Središče (1894.), Mezgovec (?) (1942.) \\
\hline Vrbno & Velika Varnica (župa Leskovec) (1901.) \\
\hline Osonjak & Gruškovje (1902.) \\
\hline Trakošćan & Teharje (1917.) \\
\hline Vranojelje & Brezovo (Vitanje) (1924.) \\
\hline Ježovec & Turski Vrh (1932.) \\
\hline Prebukovje & Vražja Vas (?) pri Ljutomeru (1938.) \\
\hline
\end{tabular}

11 HDA, MKU Bednja 1910.-1922.

12 HDA, MKV Bednja 1890.-1934., 1935.-1947. 


\section{ŽUPA DONJA VOĆA}

Donja Voća se spominje u prvom cjelovitom popisu župa zagrebačke biskupije davne 1334. godine, kao „parochia antiqua“, odnosno, „ecclesia S. Martini apud Woycha". U vrijeme osmanlijskih napadaja na krajeve u varaždinskoj okolici, župa je ukinuta, a njome upravlja župnik iz Vinice. Kasnije župnik Marko Medvedec kao moguće razloge ukinuća župe navodi ruševnost crkve, nedostatak svećenika, pomor ljudi zbog epidemija, slabo materijalno stanje župnika i župljana itd. Čini se da je glavni razlog ukinuća župe bio osmanlijska pustošenja po varaždinskom kraju i odvođenje mnogih župljana u ropstvo. Redoviti vjerski život vraća se u Voću 1651. godine. Prema zapisima iz 1808. godine, prilikom kanonske vizitacije arhiđakona Stjepana Šoštareca, navodi se da je, 13. ožujka 1651. godine, ugovorom o obvezama i pravima župnika i župljana između župske zajednice Voća (Communitatem Vochensem) i varaždinskog arhiđakona Ivana Baršića (loannes Barsich), ponovno uspostavljena bivša župa Voća. Župne matice u Voći vode se od 1681. godine. Voćanska župna crkva posvećena je 4. srpnja 1756. godine.

U župi Donja Voća je na početku dvadesetog stoljeća bilo relativno malo osoba koje su rođene u Sloveniji. Ipak, promatramo li statistiku onih koji su živjeli na području ove župe vidljivo je da je najveći broj njih živio na području Gornje Voće i da su podrijetlom bili iz graničnih zona Slovenije (Zavrč, Drenovec, Turski Vrh, Paradiž, Goričak, Korenjak), odnosno u najvećoj mjeri s područja susjedne slovenske župe Zavrč.

Tablica VII. Matična knjiga vjenčanih župe Donja Voća 1920.-1949. ${ }^{13}$

\begin{tabular}{|l|l|}
\hline Mjesto življenja & Mjesto rođenja i godina vjenčanja \\
\hline Gornja Voća & $\begin{array}{l}\text { Zavrč (1920.), Štajer (1921.), Drenovec (1922.), Spodnja } \\
\text { Hajdina (1931.), Celje (1932.) (otišli u Klenovnik) }\end{array}$ \\
\hline Budinščak & Paradiž (1925.), Zamušani (1941.) \\
\hline Plitvica & Goričak (1928.), Zavrče (1935.) \\
\hline Rijeka Voćanska & Turski Vrh (1930.) \\
\hline Jelovec Voćanski & Korenjak (1930.) \\
\hline Gradinščak & Belski Vrh (Zavrč) (1936.), Korenjak (1937.) \\
\hline Zlogonje (Višnjica) & Formin (1942.) \\
\hline
\end{tabular}

13 HDA, MKV Donja Voća 1920.-1949. 
Tablica VIII. Matična knjiga umrlih župe Donja Voća 1930.-1949. ${ }^{14}$

\begin{tabular}{|l|l|}
\hline Mjesto smrti & Mjesto rođenja i godina smrti \\
\hline Jelovec Voćanski & Župa Zavrč (1932.), Zavrč (1933.), Zavrč (1939.) \\
\hline Gornja Voća & $\begin{array}{l}\text { Zavrč (1932.), Turski Vrh (1933.), Korenjak (1934.), } \\
\text { Zavrč (1936.), Zavrč (1941.) }\end{array}$ \\
\hline
\end{tabular}

\section{ŽUPA VIŠNJICA}

Župu Blažene Djevice Marije u Višnjici utemeljio je grof Ivan Drašković i supruga Katarina Brandi s početkom 1705. godine. Gotovo cijeli teritorij župe Višnjica odcijepljen je od župe Kamenica, a tek mali dio od župe Bednja. Osim Višnjice u župu potpadaju i naselja Bednjica, Gornja Višnjica, Zalužje, Jazbina Višnjička i Zlogonje. Prema pisanju Vjekoslava Noršića svake je godine k ovoj crkvi dolazio veliki broj naroda, osobito iz susjedne Štajerske. Na području župe se nalazi kapela Svetog Florijana koja se navodi 1729. i za koju se govori da se nalazi „,in Ostaria ad metales Styriae“ (tj. u Oštariji kod štajerske granice). Ta kapela i danas stoji na granici kod sela Zlogonje. ${ }^{15}$

Najveći broj doseljenih Slovenaca na područje ove župe bio je u mjesto Zlogonje koje se nalazi uz samu hrvatsko-slovensku granicu . Oni su potjecali s područja slovenskih naselja Paradiž, Pohorje, Meje, Slatina i Veliki Okič, dakle iz susjedne župe Leskovec. To ukazuje na činjenicu da se stanovništvo župe Donja Višnjica, kao i stanovništvo ostalih pograničnih župa nije miješalo sa slovenskim stanovništvom koje je živjelo podalje od granice, već isključivo s pograničnim selima gdje je postojala mogućnost da se ljudi upoznaju u svakodnevnim susretima (na polju, u crkvi, u trgovini...)

14 HDA, MKU Donja Voća 1930.-1949.

15 Više o župi Višnjica vidi u: Vjekoslav NORŠIĆ, „Višnjica“, Tkalčić, 14, Zagreb 2010., 323-344. 
FILIP ŠKILJAN: Hrvatsko-slovenski odnosi na području granične zone Varaždinske županije

Tablica IX. Matična knjiga vjenčanih župe Višnjica 1878.-1913. i 1914.-1948. ${ }^{16}$

\begin{tabular}{|l|l|}
\hline Mjesto stanovanja & Mjesto rođenja i godina vjenčanja \\
\hline Donja Višnjica & Kranjska (1878.), Sveti Anž (1901.), Slivnica (1934.) \\
\hline Zlogonje & $\begin{array}{l}\text { Paradiž (1885.), Pohorje (1892.), Pohorje (1894.), } \\
\text { Meje (1916.), Slatina (1923.), Meje (1944.) }\end{array}$ \\
\hline Gornja Višnjica & Pohorje (1907.) \\
\hline Zalužje & 2XPohorje (1909.), Veliki Okič (1911.) \\
\hline Bednjica & Leskovec (Okič) (1941.), Veliki Okič (1946.) \\
\hline
\end{tabular}

Tablica X. Matične knjige umrlih župe Višnjica 1901.-1925. i 1926.-1948. ${ }^{17}$

\begin{tabular}{|l|l|}
\hline Mjesto smrti & Mjesto rođenja i godina smrti \\
\hline Zalužje & Sveta Barbara (Štajer) (1907.), Gruškovec (1934.) \\
\hline Zlogonje & Gruškovec (1918.) \\
\hline Donja Višnjica & Sveta Barbara (1948.) \\
\hline
\end{tabular}

\section{ŽUPA CVETLIN}

Župa u Bednji je bila u 18. stoljeću opsegom i brojem stanovnika toliko velika da ju je car Josip II. podijelio na dvije župe. U župu Cvetlin koja je ustanovljena 1789. godine ušla su naselja Cvetlin, Brezova Gora, Jamno, Jazbina Cvetlinska i Macelj. Kapela Svetog Petra u Cvetlinu tako je postala župnom crkvom. Građevina se nalazi uz samu granicu sa Štajerskom, a sagrađena je 1911. godine. Crkvu je oslikao figuralno i ornamentalno slovenski slikar Šimun Fras iz Slivnice kod Maribora 1924. i 1925. godine. Zanimljivost je da su na Smiljanovu brijegu Štajerci, Bednjanci i Cvetlinčani počeli su graditi kapelicu Svetog Križa. Nakon nekog vremena odustali su od gradnje, a još se i danas vide zidovi visoki 4-5 metara. Ta je građevina duga oko 8 metara. ${ }^{18}$ Prema matičnim knjigama župe Cvetlin čini se da su mještani slovenskog podrijetla u prvoj polovini 20. stoljeća uglavnom bili iz mjesta Velika Varnica sa slovenske strane.

\footnotetext{
16 HDA, MKV Višnjica 1878.- 1913., 1914.-1948.

17 HDA, MKU Višnjica 1901.-1925, 1926.-1948.

18 Više o župi Cvetlin vidi u: Vjekoslav NORŠıć, „Cvetlin“, Tkalčić, 14, Zagreb, 2010., 241-252.
} 
Tablica XI. Matična knjiga umrlih župe Cvetlin 1888. - $1905 .{ }^{19}$

\begin{tabular}{|l|l|}
\hline Mjesto smrti & Mjesto rođenja i godina smrti \\
\hline Župa Cvetlin & Velika Varnica (1890.) \\
\hline Cvetlin & $\begin{array}{l}\text { Velika Varnica (1891.), Velika Varnica (1894.), Velika } \\
\text { Varnica (1896.) }\end{array}$ \\
\hline Brezova Gora & $\begin{array}{l}\text { Gruškoberg (1892.), Ložane (1895.), Žitak (1896.), } \\
\text { Sveta Trojica (1902.), Optuj (1903.) }\end{array}$ \\
\hline Jazbine & Velika Varnica (1899.), Gradišče (1902.) \\
\hline Macelj & $\begin{array}{l}\text { Žetale (1901.), Sveto Trojstvo (1904.), Čemernica } \\
(1901 .)\end{array}$ \\
\hline
\end{tabular}

\section{POPISI STANOVNIŠTVA - POGRANIČNA NASELA ŽUPANIJE VARAŽDINSKE (1900.- 1991.)}

Prema popisima stanovništva iz perioda između 1900. i 1991. vidljivo je da je na području pogranične zone današnje Varaždinske županije najviše Slovenaca živjelo u naseljima Gornja Voća, Jelovec Voćanski, Budinščak, Dubrava Križovljanska, Donje Vratno, Križanče i Cestica. Najveći broj onih koji su se osjećali Slovencima živio je na tome području u vrijeme popisa 1900. godine. $U$ to su vrijeme Štajerska i Hrvatsko zagorje pripadali jednoj državi Austro-Ugarskoj Monarhiji, a granice između jedne i druge pokrajine nisu postojale. Kontinuitet povećanja broja Slovenaca na području pogranične zone moguće je pratiti između 1900. i 1991. godine jedino na području sela Dubrava Križovljanska, dok je kod najvećeg broja ostalih sela moguće vidjeti opadanje broja Slovenaca kroz dvadeseto stoljeće. Popis iz 1948. godine iskazuje pojedina naselja zajedno, pa je stoga teško ustanoviti koliko je bilo u pojedinom naselju Slovenaca. Nakon Drugog svjetskog rata moguće je, a posebno nakon sedamdesetih godina i jačanja o ideji stvaranja jugoslavenske nacije, da se jedan dio Slovenaca na tome području iskazao kao Jugoslaveni, a da se drugi dio Slovenaca u procesu asimilacije iskazao Hrvatima.

19 HDA, MKU Cvetlin 1888.-1905. 
FILIP ŠKILJAN: Hrvatsko-slovenski odnosi na području granične zone Varaždinske županije

Tablica XII. Broj Slovenaca u pograničnim naseljima nekadašnjih općina Ivanec i Varaždin ${ }^{20}$

\begin{tabular}{|c|c|c|c|c|c|c|c|c|}
\hline & 1900. & 1910. & 1948. & 1953. & 1961. & 1971. & 1981. & 1991. \\
\hline Brezova Gora & 13 & 17 & 5 & 7 & 5 & 4 & 1 & 0 \\
\hline Budinščak & 25 & 1 & $\begin{array}{l}\text { Iskazano s } \\
\text { naseljem } \\
\text { Gornja Voća }\end{array}$ & 4 & 7 & 3 & 5 & 7 \\
\hline Cvetlin & & 1 & 9 & 0 & 0 & 1 & 1 & 2 \\
\hline Donja Višnjica & 4 & 3 & 17 & 4 & 3 & 1 & 2 & 1 \\
\hline Donja Voća & 2 & 0 & 0 & 0 & 3 & 4 & 3 & 3 \\
\hline Gornja Voća & 23 & 2 & 12 & 3 & 2 & 0 & 5 & 5 \\
\hline Jamno & 1 & 1 & 0 & 3 & 0 & 0 & 0 & 3 \\
\hline $\begin{array}{l}\text { Jazbina } \\
\text { Cvetlinska }\end{array}$ & 5 & 5 & $\begin{array}{l}\text { Iskazano s } \\
\text { naseljem } \\
\text { Cvetlin }\end{array}$ & 1 & 0 & 4 & 1 & 4 \\
\hline $\begin{array}{l}\text { Jelovec } \\
\text { Voćanski }\end{array}$ & 69 & 2 & $\begin{array}{l}\text { Iskazano s } \\
\text { naseljem } \\
\text { Gornja Voća }\end{array}$ & 6 & 6 & 9 & 6 & 4 \\
\hline Pleš & & & 5 & 0 & 3 & 1 & 3 & 2 \\
\hline Zalužje & 8 & 15 & 0 & 8 & 0 & 1 & 12 & 13 \\
\hline Zlogonje & 10 & 12 & $\begin{array}{l}\text { Iskazano s } \\
\text { naseljem } \\
\text { Donja } \\
\text { Višnjica }\end{array}$ & 12 & 9 & 11 & 9 & 8 \\
\hline Babinec & 3 & 2 & 14 & 10 & 2 & 1 & 4 & 8 \\
\hline Cestica & 21 & 7 & 19 & 3 & 2 & 2 & 5 & 6 \\
\hline Donje Vratno & 23 & 0 & 1 & 3 & 0 & 1 & 1 & 0 \\
\hline $\begin{array}{l}\text { Dubrava } \\
\text { Križovljanska }\end{array}$ & 69 & 59 & 70 & 64 & 59 & 75 & 78 & 69 \\
\hline Gornje Vratno & & 15 & 0 & 0 & 0 & 2 & 2 & 6 \\
\hline Križanče & 38 & 27 & $\begin{array}{l}\text { Iskazano s } \\
\text { naseljem } \\
\text { Jarki }\end{array}$ & 3 & 3 & 5 & 2 & 2 \\
\hline
\end{tabular}

20 Jakov GELO i sur., Narodnosni i vjerski sastav stanovništva Hrvatske 1880. - 1991 po naseljima., Državni zavod za statistiku, Zagreb 1998. 


\begin{tabular}{|l|l|l|l|l|l|l|l|l|}
\hline Mali Lovrečan & 12 & 4 & $\begin{array}{l}\text { Iskazano s } \\
\text { naseljem } \\
\text { Dubrava } \\
\text { Križovljanska }\end{array}$ & 5 & 1 & 2 & 4 & 2 \\
\hline Otok Virje & 22 & 22 & $\begin{array}{l}\text { Iskazano s } \\
\text { naseljem } \\
\text { Jarki }\end{array}$ & 2 & 5 & 9 & 7 & 6 \\
\hline $\begin{array}{l}\text { Selci } \\
\text { Križovljanski }\end{array}$ & 19 & 0 & $\begin{array}{l}\text { Iskazano s } \\
\text { naseljem } \\
\text { Dubrava } \\
\text { Križovljanska }\end{array}$ & 11 & 9 & 22 & 19 & 27 \\
\hline $\begin{array}{l}\text { Veliki } \\
\text { Lovrečan }\end{array}$ & 4 & 5 & $\begin{array}{l}\text { Iskazano s } \\
\text { naseljem } \\
\text { Cestica }\end{array}$ & 22 & 18 & 25 & 2 & 11 \\
\hline $\begin{array}{l}\text { Virje } \\
\text { Križovljansko }\end{array}$ & & & & & & & 21 & \\
\hline
\end{tabular}

Tablica XIII. Broj Slovenaca između 1900. i 1991. na području općine Varaždin i općine Ivanec

\begin{tabular}{|l|l|l|l|l|l|l|l|l|}
\hline Općina & $\mathbf{1 9 0 0 .}$ & $\mathbf{1 9 1 0}$ & $\mathbf{1 9 4 8}$ & $\mathbf{1 9 5 3 .}$ & $\mathbf{1 9 6 1 .}$ & $\mathbf{1 9 7 1 .}$ & $\mathbf{1 9 8 1 .}$ & $\mathbf{1 9 9 1 .}$ \\
\hline Ivanec & 329 & 147 & 136 & 126 & 78 & 94 & 111 & 124 \\
\hline Varaždin & 1080 & 711 & 837 & 785 & 788 & 657 & 627 & 581 \\
\hline
\end{tabular}


FILIP ŠKILJAN: Hrvatsko-slovenski odnosi na području granične zone Varaždinske županije

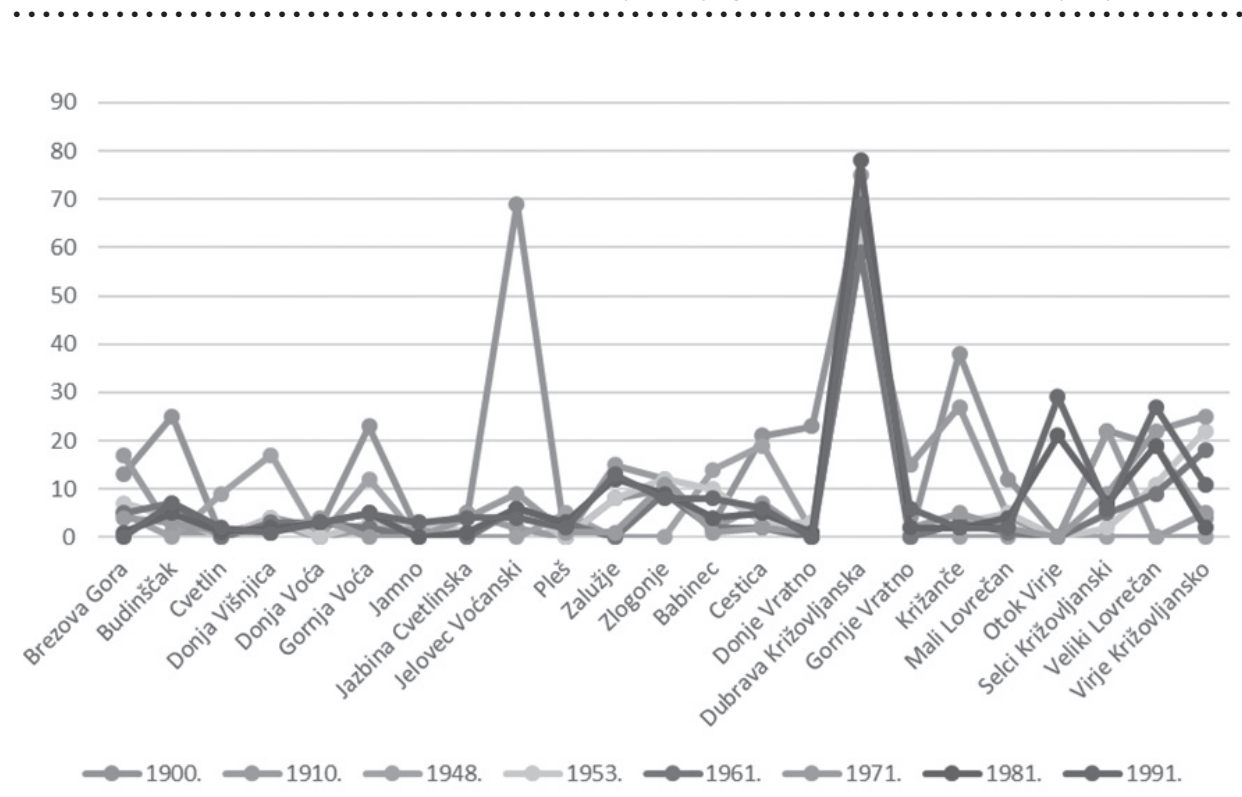

Grafikon I. Broj Slovenaca u pograničnim naseljima Varaždinske županije
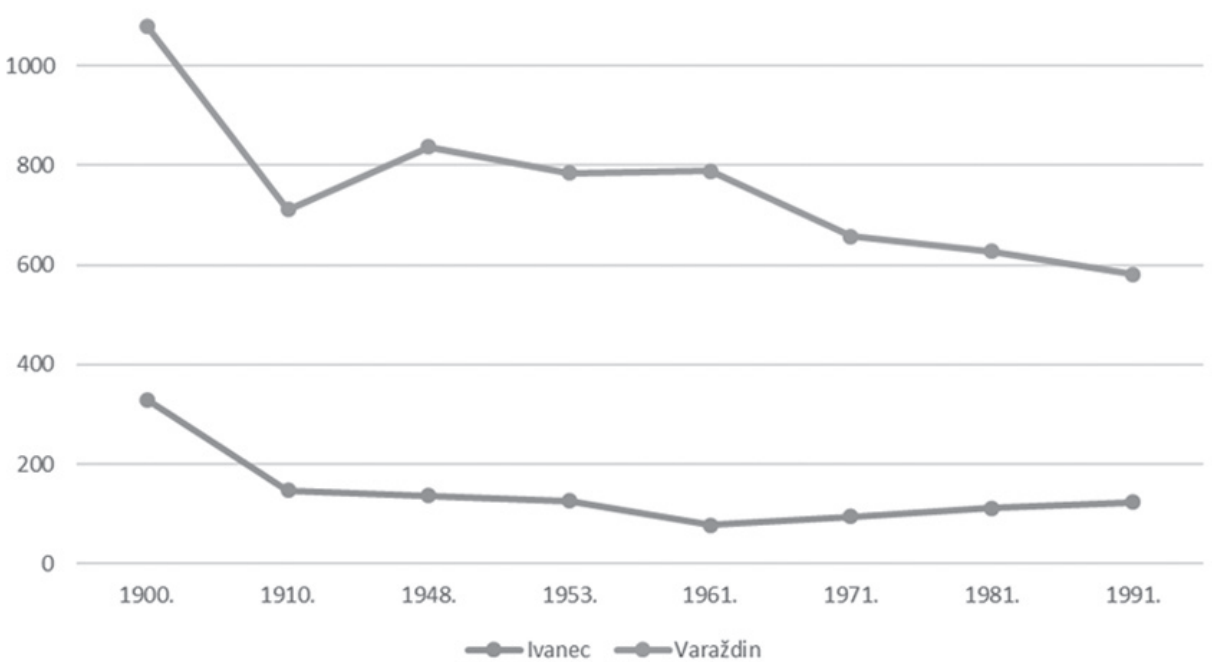

Grafikon II. Broj Slovenaca na području bivših općina Varaždin i Ivanec 


\section{ZAKLJUČAK}

Granična zona između Hrvatske i Slovenije specifičan je prostor, a podaci o ovoj mikroregiji prikupljeni su na temelju matičnih knjiga vjenčanih i umrlih te na temelju iskaza kazivača iz spomenutog područja. Matične knjige su nam ukazale na to da su u prošlosti veze između Hrvata i Slovenaca na ovom području bile intenzivne (ne toliko koliko u području Štrigove u Međimurju). Na to su nam ukazali i razgovori sa sugovornicima koji su prikupljeni na terenu. Uvođenje tvrde granice između Hrvatske i Slovenije 1991. prekinulo je intenzitet tih međunacionalnih odnosa. I na ostalim dijelovima hrvatsko-slovenske granice (npr. uz Sutlu uz Kupu i u Međimurju) ekonomske, društvene i obiteljske veze činile su okosnicu međunacionalnih odnosa Hrvata i Slovenaca. Matične knjige su nam otkrile koliko su u povijesti te veze bile uske, a razgovori s ispitanicima ukazali su nam da su ljudi s jedne i druge strane granice bili povezani na svaki mogući način. Iz svih razgovora koji su vođeni 2019. osjeća se da stanovništvo pograničnog prostora žali za nekadašnjim i zajedništvom bez granica prije 1991.

Podaci koji su prikupljeni ukazali su na činjenicu da je granica prekinula nekadašnje kvalitetne, bliske međunacionalne odnose. Na mikrolokacijama pogranične zone u Varaždinskoj županiji ti odnosi su presječeni i žičanom ogradom koja dodatno otežava odnose Hrvata i Slovenaca, a koje je postavila visoka politika koja ne shvaća da na taj način uništava stoljećima stvarane uske hrvatskoslovenske međunacionalne dodire.

\section{POPIS IZVORA I LITERATURE}

\section{Literatura}

1/ GELO, Jakov i sur., Narodnosni i vjerski sastav stanovništva Hrvatske 1880. 1991 po naseljima., Državni zavod za statistiku, Zagreb, 1998.

2/ KOŠIĆ, Ivan, Povijest župe Križovljan, Varteks Tiskara, Varaždin, 1987.

3/ NORŠIĆ, Vjekoslav, „Bednja“, Tkalčić, 14, Zagreb, 2010., 195-240.

4/ NORŠIĆ, Vjekoslav, "Cvetlin“, Tkalčić, 14, Zagreb, 2010., 241-252.

5/ NORŠIĆ, Vjekoslav, „Višnjica“, Tkalčić, 14, Zagreb 2010., 323-344.

6/ ŠKILJAN, Filip, Slovenci u Varaždinu i Varaždinskoj županiji, SKD Nagelj, Varaždin, 2015. 


\section{Kazivači}

1/ Bednjički, Petar, 1949., Bednjica

2/ Benko, Karel, 1947., Gerlinci (sada općina Cestica)

3/ Bistrović, Mirko, 1949., Bednja

4/ Borak, Marija, 1946., Šmarje pri Jelšah (sada općina Cestica)

5/ Bukovec, Vlatko, 1947., Donja Voća

6/ Cvetko, Vjekoslava, 1947., Budinščak

7/ Hočurščak, Goran, 1969., Varaždin (Donja Višnjica)

8/ Horvatić, Barica, 1945., Rijeka Voćanska

9/ Juričinec, Elizabeta, 1942., Gornja Radgona (sada Radovec)

10/ Križanec, Josip, 1949., Donja Višnjica

11/ Križnjak, Marija, 1925., Rijeka Voćanska

12/ Milešić, Blaž, 1950., Budinščak

13/ Mumlek, Ana, 1946., Loče pri Poljčanah (sada Babinec)

14/ Patrčević, Đurđica, 1960., Varaždin (Slivarsko)

15/ Pintarić, Adam, 1955., Podgorje Bednjansko

16/ Topolovec, Terezija, 1949., Goričak (Zavrč), (sada općina Cestica)

17/ Višinski, Ivan, 1957.g., Gornja Višnjica

\section{Izvori}

\section{Hrvatski državni arhiv (dalje HDA)}

HDA, Matična knjiga umrlih (dalje MKU) Nadkrižovljan 1902.-1929., 1930.-1949.

1/ HDA, Matična knjiga vjenčanih (dalje MKV) Nadkrižovljan 1902.-1929., 1930.-1949.

2/ HDA, MKU Križovljan 1901.-1934., 1935.-1949.

3/ HDA, MKV Križovljan 1912.-1948.

4/ HDA, MKU Bednja 1910.-1922.

5/ HDA, MKV Bednja 1890.-1934., 1935.-1947.

6/ HDA, MKV Donja Voća 1920.-1949.

7/ HDA, MKU Donja Voća 1930.-1949.

8/ HDA, MKV Višnjica 1878.- 1913., 1914.-1948.

9/ HDA, MKU Višnjica 1901.-1925, 1926.-1948.

10/ HDA, MKU Cvetlin 1888.-1905. 


\section{SUMMARY}

\section{CROATIAN-SLOVENIAN RELATIONS IN THE BORDER ZONE OF VARAŽDIN COUNTY}

The author provides information on Croatian-Slovenian relations in the Varaždin County. The area of the border in scientific terms has been very rarely viewed through the testimonies of people living in the border area, and therefore this research is different, since it is based on the experience of people living along the Croatian-Slovenian border. The study found that residents on both sides of the border were much more oriented towards each other than connected to their regional centers. The border has greatly disrupted relations between Croats and Slovenes on both sides. This paper seeks to show in what ways there were links between one space and another, and how much those links were broken after the 1991 border was established. The research applied the historical and ethnological approach that is evident from the collection of data from the registers of the deceased and the married, or from the method of oral history and storytelling. Based on the registers of deceased and married parishes in Nadkrižovljan, Križovljan, Višnjica, Voća, Cvetlin and Bednja, the author provides information on the intensity of contacts between Croats and Slovenes in the border zone of Varaždin County. It can be seen that these links have been tight over a nearly five hundred-year history in the common state. Interviews conducted in the area of the City of Lepoglava and the Municipality of Donja Voća and the Municipality of Bednja show that the inhabitants of the border zones have always been economically, socially and family-related to nearby Slovenia.

Key Words: Varaždin County; Croatian-Slovenian relations; Lepoglava; Donja Voća; Cestica; Bednja. 
